Copyright (C) 2019 by Academic Publishing House Researcher

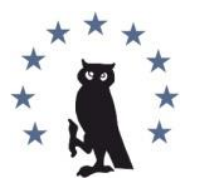

Published in the Russian Federation

European Researcher. Series A

Has been issued since 2010.

E-ISSN 2224-0136

2019, 10(3): 196-205

DOI: $10.13187 /$ er.2019.3.196

www.erjournal.ru

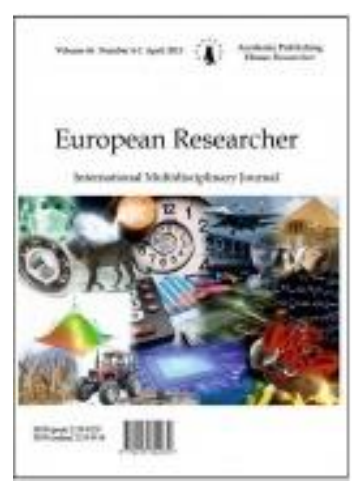

\title{
Environmental Practices in Sarajevo Luxury Hotels
}

\author{
Lejla Žunić a , *, Aida Bidžan-Gekić a, Haris Gekić a \\ a University of Sarajevo, Bosnia and Herzegovina
}

\begin{abstract}
The aim of the article was to identify and evaluate environmental practices in Sarajevo luxury hotels. The objectives were to: 1) analyse the development trend in hospitality industry; 2) present a negative environmental impacts of hotels \& tourism activities; 3) present concept of green hotel; 4) identify and evaluate green attributes in lux 5-star hotels; 5) identify benefits of green hotel policy (GHP). There was given a theoretical background to show the correlation of Sarajevo tourism \& hospitality development and the real need for GHP. The mix of Millar \& Baloglu (2008) and GC-MARK (2013) survey models were applied to get the information on green practices in lux hotels at Sarajevo. The survey results were presented within the 5 categories: Knowledge of GHP, Energy Saving, Water Saving, Recycling \& Waste Disposal and Hygienic \& Re-Use Program. We found decent majority of environmental attributes in lux hotels. Therefore, energy saving is most preferred, while the water saving and recycling are the least preferred. However, the lux hotels' participation in green practices is somewhat neutral mostly due to the lack of governmental support. The research provided green concept for hoteliers and the recommendations for sustainable hospitality.
\end{abstract}

Keywords: Sarajevo, luxury hotels, green concept, environmental practices, GHP, sustainable hospitality.

\section{Introduction}

Sarajevo, Bosnia and Herzegovina is a European developing tourism destination. The administrative area of Sarajevo tourism destination could be defined with its 5 urban municipalities because there's a majority of the tourism reception contents (accommodation, catering, transport, information, museums and tourist attractions).

Sarajevo has a very convenient location on the European tourism corridor as it connects the continental Middle Europe and the Mediterranean Europe (Nurkovic et al., 2006). Sarajevo is also well connected with East Europe (Kurtovic, 2008). Sarajevo is the capital and the leading tourism destination in Bosnia and Herzegovina with the contemporary developing charter programs. Therefore, Sarajevo begins to open its tourism gate not only to the Europe but to the rest of the World as well.

Sarajevo is no longer "taboo" destination but the place worth to visit it because of its unique multicultural connection of "Oriental" East \& "European" West (Johanson, 2014).

Sarajevo has a positive tourism growth throughout the two passed decades, e.g. the total number of tourist arrivals grew from 103.977 in 2005 to 462.793 in 2017. The number of nights

\footnotetext{
${ }^{*}$ Corresponding author

E-mail addresses: pmflejlazunic@yahoo.com (L. Žunić)
} 
spent in tourist accommodation increased by $9 \%$, reaching approx. 1 million nights in 2017 (925.198). There was a high participation of international overnight stays $89 \%$. The hospitality industry of Sarajevo had a gross traffic of 200 million $€$ in 2017 and the net profit of 3 million $€$ (Development Planning Institute of Canton Sarajevo). The managers at the tourism sector claim that the real tourism indicators might have a higher value but there's statistical leakage at some hotels or private accommodation, e.g. malversation at the registration of overnight stays (Zunic, 2018).

The tourism development has been especially followed with a progressive growth rate of accommodation by $20 \%$. Most of the hotels were burnt during the last war (1992-1995) but nowadays when the tourism is blooming there is a huge need for creating the basic tourist reception such as hotels... Bibanovic (UTA BiH) inquired the quality of the progressive trend of hotels development in Sarajevo (quantity vs. quality) but there's been improving lately with a significant growth of the popular lux and superior hotels (e.g. Swissotel, Hills, Marriot...). The total number of accommodation units was 160 in 2017 while the "hotels" take the half part in it (Federal Ministry of Environment and Tourism). However, the lux category/ five-star hotels share was $12 \%$ only (Hills, Malak, Swissotel, Evropa, Radon Plaza, Austria \& Bosna).

Hotel industry has made a lot of changes in the city ambient. Right after the war the development of accommodation wasn't planned well- without a clear spatial concept. This resulted at building some basic \& simple linear hotels and motels (e.g. along the city route) or at the previous abandoned industry zone. On the other hand, the five-star hotels have a nice and well planned location. Majority of the lux hotels $67 \%$ is located on the southwest of destination because of the thermal water resources. That's about $10-15 \mathrm{~km}$ distance from the city centre. This area is also wealth with freshwater and high biodiversity and it's near to the protected area (Natural Monument Vrelo Bosne). Therefore, it's important to evaluate the hotel's environmental policy and practices. There was found concerning results at the 8 superior and lux hotels in Sarajevo (Kadric, 2018) with no pro-environmental policy as almost half of employees had a negative attitude $46 \%$ followed with neutral attitude by $44 \%$. More than half of the tourism managers evaluated the moderate environmental threat for the Sarajevo tourism destination. However, some of them showed the concern of the high negative environmental impacts of tourism $10 \%$ (Zunic, 2018). As Sarajevo is a developing tourism destination with the progressive trend of hospitality development especially in the area that is rich with good waters and near to the protected area, the concern about environment should be priority.

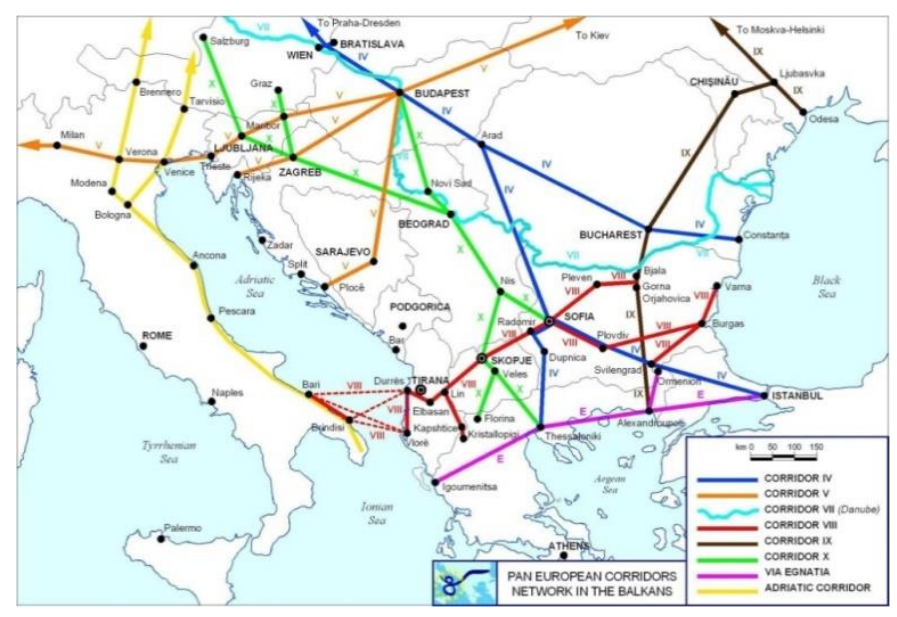

Fig. 1. Position of Sarajevo at the Pan European corridor network in the Balkans; Corridor V (Sarajevo, Bosnia \& Herzegovina) is one of the main European tourism corridors which connects the Middle Europe with the Mediterranean Europe Source: Strategies of the Pan-European Transport Corridors and Transport Areas, 2002 


\section{A Theoretical Background}

\subsection{Negative environmental impacts of hotels \& tourism activities}

The invasive hotel industry might cause negative environmental impacts. Even tourism is generally considered a "clean" industry, one that is based on hotels etc., it can also degrade an environment. Visitors generate waste and pollution (air, water, solid waste, noise, and visual), while the natural landscape and open space can be lost (Kreag, 2001). Hotels produce $1 \mathrm{~kg}$ of waste per guest per day (Müller, 2004).

Negative environmental effects of tourism activities: construction hotels produce the noise pollution which might negative affect wildlife (e.g. nesting birds); disposal of waste into water bodies or increase water consumption; clearing habitat for construction and tourism facility (Leung et al., 2014).

There is also relation between tourism and water shortages. The water consumption at tourist accommodation rates in a range between 84 and $2000 \mathrm{~L}$ per tourist per day. Overall, there is a tendency for higher-standard accommodation to consume significantly higher water volumes such as hotels with spas and large or multiple swimming pools. Higher laundry volumes per guest per day are a result of sport and health centres, as well as affected by textile quality and/or weight of laundry items, including very large towels for spa facilities etc. The major proportion of water spent for direct uses including taking showers, flushing the toilet, and the use of tap water $(55 \%, 136 \mathrm{~L}$ per tourist per day), with a corresponding consumption of 20 per cent or 186 L per tourist per day in hotels (Gössling et al., 2012).

Therefore, tourism \& hotel blooming over the last years in Sarajevo could be the reason for some typical undesirable environmental impacts. For example, the water shortages during tourism season were evident over the last 2 years while there was at the same time evident building of new resorts in the upper water area of river Bosnia.

According to WRAP, hotels dispose of 600.000 tonnes of compostable food waste each year, in addition to palpable and recyclable waste products such as paper and packaging. In Bosnia and Herzegovina, total quantity of generated waste was 58.343 .502 tons in 2010, while the majority came from mining, manufacturing and energy production. The estimated quantity of produced communal waste (industry, trade and service industry) for 2010 is 1.521 .877 tons, which is $396 \mathrm{~kg}$ per person/a year or $1.08 \mathrm{~kg}$ per person/day. In the total quantity of the collected waste, the mixed communal waste participates with $92.4 \%$, separately collected communal waste with $6.0 \%$, waste from gardens and parks with $1.1 \%$ and packaging waste with $0.4 \%$. In 2010, 1.516.423 tons of waste was disposed on landfills. However, there is no certain data of the waste that comes from the tourism and hospitality activities directly (Council of Ministers, Bosnia \& Herzegovina, 2012), but only the general perception that there's larger amount of waste during the tourism season.

There's undeniable negative environmental impacts derived from hotel activities. Thus, green practices should be widely used and implemented in hotel industry (Deraman et al., 2017). "Hospitality with responsibility" is the present need (Amandeep, 2017).

\subsection{Green hotels \& its popularity (the Preferences of managers \& customers)}

The green hospitality has started in mid 1990s, initiated by chain affiliated hotels and resorts. Among the highlighted benefits are monetary and competitive advantage, customer loyalty, recognition, brand value, and employee retention. The green hotel is an environmental-friendly, whose managers are dedicated to set up program that specifically works in preserving the environment. For example, many hotels now practicing changing the bed sheet and towels upon the request only, which reduce the usage of water and electricity, also reduce the amount of detergent discharged into the sewer system (Deraman et al., 2017).

The term "green hotels" describes hotels that strive to be more environmentally friendly through the efficient use of energy, water, and materials while providing quality services (Amandeep, 2017). Green hotel promotes and practices energy efficiency, conservation, and recycling, while at the same time providing hotel guests with a sustainable, clean, and healthy product (Millar, Baloglu, 2008). The concept of a green hotel has 3 basic elements: construction \& implementation of eco-equipment, hotel environmental policies and procedures, and the green hotel marketing to internal and external customers (Amandeep, 2017).

Consumers no longer accept just linen and towel re-use programs but they also wanted such things as energy efficiency, a proper waste division, procurement, and water conservation. Many of 
the bigger cities had a growing mass of hotels competing for the LEED certifications so they would be considered a green hotel. One of the reasons behind the adoption of sustainable measures appeared to be ethics. An innovative hotelier should recognize this trend and adopt hotel green practices as a strategic move towards a competitive advantage (Ogbeide, 2012).

The three main factors influencing the implementation of green practices in hotels: cost, consumers' support, and employees' support. Many managers assume that green practice come with more investment, while the cost depending on 2 factors: a) the type of hotels, and b) the type of green practice. The customers' eco-friendly attitudes are strongly associated with positive intentions to pay more for green product (Deraman et al., 2017).

As any spatial activity, hotel industry must implement an environmental policy at least in the part that is related to the local planning permission and the study of environmental effects. Building lux hotels and resort settlements in Sarajevo usually occupy the best locations of destination. It's often nearby valuable natural resources such as freshwater, thermal water or forest. Some residents and local institutions, e.g. non-governmental foundation, etc. showed the concern about the hotel negative impact on the environment. It came mostly because of partly transparent system of making decision where to build hotels. The survey findings from the Sarajevo lux hotels showed that GHP is not the manager's primary goal but their guests' satisfaction. Hospitality industry in Sarajevo has not been focused to the green concept yet, while the main hoteliers' interest was to create a pleasant surrounding for visitors. The green hotels were not identified here, but there were found some green attributes at the Sarajevo lux hotels.

\section{Methodology}

The target population for this study were head managers/or the representative employees at the 6 lux five-star hotels in Sarajevo. The adopted mix of 2 environmental survey models - Millar and Baloglu (2008) and GC-MARK (2013) was applied and conducted into sampled hotels.

The survey was directly (face-to-face meetings)/ or indirectly (via e-mail) administered and collected in January of 2019. It consisted qualitative and quantitative questions related to over 30 environmentally friendly hotel attributes categorized at the five main sections: Knowledge of Green Hotel Policy (2), Energy Saving (10), Water Saving (7), Recycling \& Waste Disposal (6), and Hygienic \& Re-Use Program (6).

Respondents' attitudes were measured at the 5 -point Likert scale $(1=$ Strongly Disagree, $2=$ Disagree, $3=$ Neutral, $4=$ Agree and $5=$ Strongly Agree), while the evaluation model was based on determining the positive ( 4 and 5 ) and negative $(1,2)$ statements or even the neutral value $(3)$.

Validated or representative reference- relevant frequency (like dominant majority or "general attitude") was accepted if percentage $\geq 60$ (Statistical Service Centre, 2001), while the typical statistical majority was counted as the $50 \%+1$ (CEO).

Descriptive statistics were used to analyse the existence of the environmental practices at luxury hotels in Sarajevo (1) and to show the managers' knowledge of GHP (2).

\section{Results}

Table 1. Knowledge of the Green Hotel Policy (GHP)

\begin{tabular}{|lllllll|}
\hline Q1,2 & SA & A & N & D & SD & Total \\
\hline GHP Public Statement & 0.0 & 33.3 & 66.7 & 0.0 & 0.0 & 100.0 \\
Workers know \& respect GHP & 33.3 & 33.3 & 33.3 & 0.0 & 0.0 & 100.0 \\
\hline
\end{tabular}

SA - strongly agree, A - agree, $\mathrm{N}$ - neutral, D - disagree, SD - strongly disagree

Source: The survey based on the adopted mix of 2 environmental survey models - Millar and Baloglu, 2008 and GC-MARK, 2013 and conducted into 6 Sarajevo lux hotels,

Sarajevo, January, 2019)

Majority of managers or the employees in charge to respond the survey were neutral toward the existing of GPH Public Statement (67.7\%). On the other hand, a full third of respondents have knowledge of GPH Public Statement. 
According to the Council of Ministers, Bosnia \& Herzegovina (2012), there is no framework law or the strategic document governing environmental protection or sustainable development at the state level. However, there are several documents which purpose is to regulate environmental protection issue, but none of them including particularly the GPH Public Statement. In the Federal Environmental Strategy 2008-2018 (Strategy of FBiH), a high degree of coordination and cooperation with other relevant sectors was ensured through inter-sectoral council, with representatives from the following sectors: spatial planning, water management, energy, transport, etc. Between the institutions in charge for implementation of the Federal Strategy are: FBiH Ministry of Environment and Tourism and FBiH Ministry of Spatial Planning (Council of Ministers, $\mathrm{BiH}$, 2012). Those should take responsibilities in the hotels' construction \& implementing GHP.

However, the majority of respondents know and respect GHP (67.7\%), yet the sampled hotels in Sarajevo don't have a certificated green concept and they are not registered as green hotels.

Table 2. Energy Saving

\begin{tabular}{|c|c|c|c|c|c|c|}
\hline Q1-10 & $\mathbf{S A}$ & $\mathbf{A}$ & $\mathbf{N}$ & $\mathbf{D}$ & SD & Total \\
\hline $\begin{array}{l}\text { Renewable sources of energy; local produce } \\
\text { partnership }\end{array}$ & $33 \cdot 3$ & 16.7 & $33 \cdot 3$ & 16.7 & 0.0 & 100.0 \\
\hline Local products (200 $\mathrm{km}$ radius) & 16.7 & 33.3 & 50.0 & 0.0 & 0.0 & 100.0 \\
\hline Occupancy sensors & $83 \cdot 3$ & 0.0 & 0.0 & 16.7 & 0.0 & 100.0 \\
\hline $\begin{array}{l}\text { Smart key cards- turn power to the room On/ } \\
\text { Off }\end{array}$ & $83 \cdot 3$ & 16.7 & 0.0 & 0.0 & 0.0 & 100.0 \\
\hline Energy-efficient heating system & 83.3 & 16.7 & 0.0 & 0.0 & 0.0 & 100.0 \\
\hline Energy saving bulbs in the sleeping area & 66.7 & 0.0 & $33 \cdot 3$ & 0.0 & 0.0 & 100.0 \\
\hline Energy saving bulbs in the guest bathroom & 66.7 & 16.7 & 16.7 & 0.0 & 0.0 & 100.0 \\
\hline Efficient modern refrigerators and LED-TV's & 83.3 & 16.7 & 0.0 & 0.0 & 0.0 & 100.0 \\
\hline $\begin{array}{l}\text { Monitoring of energy consumption; Reducing } \\
\text { actions }\end{array}$ & $33 \cdot 3$ & 16.7 & $33 \cdot 3$ & 16.7 & 0.0 & 100.0 \\
\hline Minimizing fossil-fuel use & 50.0 & $33 \cdot 3$ & 16.7 & 0.0 & 0.0 & 100.0 \\
\hline
\end{tabular}

Source: The survey based on the adopted mix of 2 environmental survey models - Millar and Baloglu, 2008 and GC-MARK, 2013 and conducted into 6 Sarajevo lux hotels, Sarajevo, January, 2019

Half of managers gave a positive statement that hotel use energy from renewable sources and they do have a partnership with local producers. They prefer local products (200 $\mathrm{km}$ radius) not only because of less negative impact on the environment but it is economic and practical as well. This is mostly because the lux hotels are located at the area with thermal water which they use for heating etc. Therefore, there was a positive statement that hotel has an energy-efficient heating system (83.3\%). Consequently, thus 6 hotels are using sustainable, carbon neutral energy sources.

Majority of respondents (83.3 \%) strongly agreed that hotel use timers and motion detectors to optimize energy use (Occupancy Sensors) and the smart key cards (Turn Power to the Room On/Off). The hotel rooms have an efficient modern refrigerators and LED-TV's. Hotel use energy saving bulbs in the sleeping area (66.7 \%) and in the guest bathroom (83.4\%). This is typical for the lux five-star hotels as they should follow the modern trends and provide scalable technology.

Half of hotels' managers had a positive attitude toward the monitoring of energy consumption and they stated that hotel take action to reduce it, while a full third of respondents was neutral and one of them even disagreed with this statement. 
Table 3. Water Saving

\begin{tabular}{|lllllll|}
\hline Q1-7 & SA & A & N & D & SD & Total \\
\hline $\begin{array}{l}\text { Total water consumption being } \\
\text { registered on a monthly basis }\end{array}$ & 83.3 & 16.7 & 0.0 & 0.0 & 16.7 & 100.0 \\
$\begin{array}{l}\text { A filter system for an efficient } \\
\text { water usage \& guest information }\end{array}$ & 33.3 & 33.3 & 16.7 & 16.7 & 0.0 & 100.0 \\
$\begin{array}{l}\text { Low flow toilets (6l) } \\
\text { Low flow faucets }\end{array}$ & 33.3 & 0.0 & 66.7 & 0.0 & 0.0 & 100.0 \\
Low flow showerheads & 0.0 & 16.7 & 50.0 & 16.7 & 0.0 & 100.0 \\
Low flow sinks & 0.0 & 0.0 & 83.3 & 16.7 & 0.0 & 100.0 \\
Hotel use rain water, e.g. for & 16.7 & 33.3 & 33.3 & 16.7 & 0.0 & 100.0 \\
flushing toilets & 0.0 & 0.0 & 16.7 & 33.3 & 50.0 & 100.0 \\
\hline
\end{tabular}

Source: The survey based on the adopted mix of 2 environmental survey models - Millar and Baloglu, 2008 and GC-MARK, 2013 and conducted into 6 Sarajevo lux hotels,

Sarajevo, January, 2019)

Hotel room "green" (eco) attributes from the section of water saving were minimal. Most statements were negative (e.g. hotel don't use rain water for any purpose) or neutral (e.g. low flow faucets or showerheads). Half of respondents agreed or strongly agreed that hotel use low flow sinks. However, majority of respondents (66.6 \%) confirmed that hotels have a filter system and all guests are informed about efficient water usage. There was strongly positive statement that total water consumption is being registered on a monthly basis $(83.3 \%)$.

Table 4. Recycling and Waste Disposal

\begin{tabular}{|c|c|c|c|c|c|c|}
\hline Q1-6 & SA & $\mathbf{A}$ & $\mathbf{N}$ & D & SD & Total \\
\hline Recycling bins & 0.0 & 16.7 & 50.0 & 33.3 & 0.0 & 100.0 \\
\hline $\begin{array}{l}\text { Hotel has possibility to separate waste in } \\
\text { rooms, e.g. plastic and paper }\end{array}$ & 16.7 & 0.0 & $33 \cdot 3$ & $33 \cdot 3$ & 16.7 & 100.0 \\
\hline $\begin{array}{l}\text { Hotel in general prefer recyclable } \\
\text { products in recyclable packaging }\end{array}$ & 0.0 & 0.0 & 66.7 & 16.7 & 16.7 & 100.0 \\
\hline $\begin{array}{l}\text { Hazardous chemicals are stored in a } \\
\text { secure place, at a safe distance from } \\
\text { water sources }\end{array}$ & $83 \cdot 3$ & 16.7 & 0.0 & 0.0 & 0.0 & 100.0 \\
\hline $\begin{array}{l}\text { Hotel use refillable shampoo \& soap } \\
\text { dispensers }\end{array}$ & $33 \cdot 3$ & 50.0 & 16.7 & 0.0 & 0.0 & 100.0 \\
\hline Hotel buy eco-friendly toilet paper & 33.3 & 16.7 & 33.3 & 0.0 & 16.7 & 100.0 \\
\hline
\end{tabular}

Source: The survey based on the adopted mix of 2 environmental survey models - Millar and Baloglu, 2008 and GC-MARK, 2013 and conducted into 6 Sarajevo lux hotels,

Sarajevo, January, 2019)

All respondents strongly agreed (83.3 \%) or agreed (16.7 \%) that hazardous chemicals are stored in a secure place, at a safe distance from water sources. This is something that had to be respected within the fact that hotels are located at the water quality protection area. Therefore, the hotels prefer ecological products such as refillable shampoo and soap dispensers $(83.3 \%)$, or the eco-friendly toilet paper (50\%).

Half of respondents were neutral toward the recycling bins, while a full third of them disagreed to this matter. Half of respondents had negative attitude toward the separated waste in a guest room. Majority of hotel managers were neutral (66.7) about the recyclable products in recyclable packaging. Obviously, there was no particular thinking or special concern in that part. 
Table 5. Hygienic \& Re-Use Program

\begin{tabular}{|c|c|c|c|c|c|c|}
\hline Q1-6 & $\mathbf{S A}$ & $\mathbf{A}$ & $\mathbf{N}$ & $\mathbf{D}$ & SD & Total \\
\hline $\begin{array}{l}\text { Hotel use efficient shading systems, e.g. } \\
\text { blackout curtains, shutters, and blinds }\end{array}$ & 83.3 & 16.7 & 0.0 & 0.0 & 0.0 & 100.0 \\
\hline Sheets changed upon request only & 0.0 & 0.0 & 0.0 & $33 \cdot 3$ & 66.7 & 100.0 \\
\hline Towel re-use programs & $33 \cdot 3$ & 16.7 & 16.7 & 0.0 & 33.3 & 100.0 \\
\hline $\begin{array}{l}\text { Efficient and effective procurement } \\
\text { system (FIFO, merchandise control, } \\
\text { seasonal purchase, etc.) \& specialized } \\
\text { hygiene standards (e.g. meat) }\end{array}$ & 50.0 & $33 \cdot 3$ & 16.7 & 0.0 & 0.0 & 100.0 \\
\hline $\begin{array}{l}\text { Room ventilation system is inspected at } \\
\text { least once a year } \\
\text { Maiority of non-smoking rooms }\end{array}$ & 100.0 & 0.0 & 0.0 & 0.0 & 0.0 & 100.0 \\
\hline $\begin{array}{l}\text { least } 80 \text { percentage) \& a large non- } \\
\text { smoking section in restaurants and bars }\end{array}$ & 100.0 & 0.0 & 0.0 & 0.0 & 0.0 & 100.0 \\
\hline
\end{tabular}

Source: The survey based on the adopted mix of 2 environmental survey models - Millar and Baloglu, 2008 and GC-MARK, 2013 and conducted into 6 Sarajevo lux hotels, Sarajevo, January, 2019)

There was majority of positive statements toward the hygienic and re-use program at hotels (67\%). The lux hotels have a majority of non-smoking rooms (at least $80 \%$ ) and there is a large non-smoking section in restaurants and bars.

Room ventilation system is inspected at least once a year (100 \%). Majority of respondents strongly agreed $(83.3 \%)$ or agreed $(16.7 \%)$ that the hotel rooms have an efficient shading system (e.g. blackout curtains, shutters, or the blinds). Hotels mostly have an efficient and effective procurement system (FIFO, merchandise control, seasonal purchase, etc.) and specialized hygiene standards (e.g. fish, meat, etc.).

This 4 was the most preferred hotel green attributes, while changing sheets upon request was not preferred at all.

On the other hand, towel re-use program in the guest room was also received well with $50 \%$ positive (strongly agree 33.3 and agree 16.7 ) responses.

\section{Discussion}

Managers are mostly neutral toward the Green Hotel Policy and its Public Statement which means it is not officially accepted or implemented. The available documents don't precise GHP and there's no official strategy of sustainable hotels development (nothing like legislative "sustainable strategies for green hotel design" or "sustainable development plan in hospitality"). The previous research showed the majority of tourism managers don't even know about the plan or strategy of Sarajevo tourism development, while 20 \% of them guessing it might exist but it's probably too general (Zunic, 2018). Planned investments in environmental infrastructure (2007-2011) didn't include anything for the sustainable hospitality but there was some "green" building in 2016, e.g. Tarcin Forest Resort \& Spa - a green tourism settlement at Sarajevo surroundingsinternational project in cooperation with Kuwait investors.

Lux hotels in Sarajevo have majority of green attributes from the section of Energy Saving. The thing that was helping toward this concept was the hotels' favourable location and their "core" (grouping) distribution around the thermal water resources. The hotels provide modern eco technology \& equipment not only because of reducing the negative impact on the environment but for their economic benefits as well. They practice energy saving also because they follow the modern standards of high quality and innovations: as the five-star hotels they must show their prestige. At the same time, all lux hotels should be completely aware of need for monitoring of energy consumption and take action to reduce it. Hotel managers/or hotelierd could initialize the steps to create a strategy of sustainable hospitality at the Sarajevo tourism destination.

Water Saving and its usage at the lux hotels is weakly regulated with eco saving water equipment. This is not only important for saving the amount of water but for saving the contamination of underground receptive waters. The lower pressure would behave, figuratively speaking, as filter because it would significantly reduce the overall spending of water. Anyhow, the 
most important thing to the hotel managers is the guests' satisfaction. They prefer clean rooms and that guests can use water profusely rather than to complain of it. For instance, in the past, low flow showerheads have not provided much water pressure, but they are improved lately and they provide regular water pressure today. Eco water equipment usually has a great quality and there's no objective obstacle to not to use it and be contented. On the other hand, such equipment is mostly certificated and it cost more (e.g. eco-friendly faucets). Hoteliers sometimes rushing to finalize their project with financial reduce. Therefore, they rather reduce their investment into equipment during a building stage without a long-term thinking of environmental consequences \& sustainable development. For example, eco-faucets costs more, but they save more water and decrease the monthly payment of water consumption.

There was a full third of positive statements in the section of Recycling and Waste Disposal. However, waste disposal was more preferred then the recycling. Storing the hazardous chemicals and the use of refillable dispensers received the highest mean out of all the attributes in this section. This preference was followed closely by use of eco-friendly toilet paper. On the other hand, waste recycling received the most negative or neutral responses. That's because there's no recycling politics or an efficient mechanism at the city or neither at the state level. According to the public communal service (KJKP Rad, Sarajevo), during summer and winter tourist season, there was disposing of larger amount of waste, because of increased number of visitors. However, hoteliers stated there's a selective recycling and redemption program of waste (e.g. packaging, medicine, metals, or even oils from the kitchen). Inspectorate of urban-building, environmental and communal inspections of Sarajevo Canton has 2 sectors for the environmental protection since 2016, but they are not responsible for carrying out the regular environmental control in hotels. They do the checks only if there was reported some irregularities that might cause the environmental hazards. According to this inspectorate, nothing like that has happened by now. However, the Report of Environmental Issue - Bosnia \& Herzegovina (Council of Ministers, 2012) showed the lack of data linked to the waste caused by tourism, as well as missing relevant information of environmental efficiency of tourism, or use of energy in the tourist accommodation, etc. This report at state level is relevant for Sarajevo Canton too (Cantonal Plan of Environmental Protection of Sarajevo Canton 2016-2021, Sarajevo). Therefore, there are some initial projects in this side covered with UN support (UN-Environment and UN-Habitat), but none of the lux hotels don't have the separate waste program at rooms yet which would simple start and at the same time, good support to the recycling programs at the higher spatial level.

Hygienic and Re-Use Program is very well received at the lux hotels in Sarajevo. The only exception was found at the sheets changed upon the request only. This is something that lux five-star hotels couldn't afford easily as they have an image of a high quality and comfort. Clean rooms and the fresh sheet is the least that guest expecting in such hotels as the customer satisfaction comes first.

Finally, we found 16 positive of a total 31 statements which means that lux hotels in Sarajevo have a statistical majority of environmental attributes (52 \%), but it's still not a common or general presented. Between the 5 sections, Energy Saving is most preferred, while the Water Saving is the least preferred. This one is followed with Recycling.

Many of managers or employees already have some knowledge about environmentally practices in the hotel industry but they rather know about the economic benefits of eco products so they welcome them in a hotel room. Millar \& Baloglu (2008) suggested that "hotels provide various levels of environmental attributes, and their first step may be to change all faucets to eco saving faucets". Therefore, all the lux hotels in Sarajevo may follow this instruction. At the same time, as Sarajevo is kind a "rainy" city, hoteliers could also start using the rain water for flushing the toilets, etc.

"It is not only necessary for the hotel to have environmental policies in place, but it is also necessary to both promote the fact that the hotel actually has those policies in place, and promote the guest to get involved" (Millar, Baloglu, 2008). A strategic hotelier should price rooms competitively with adequate promotions to curtail the potential negative perceptions (Ogbeide, 2012). Hotel guests would participate in the green programs because they can afford to pay some more to show their support in preserving the environment. The management should give good example in supporting green practice, in order for the employees to practice it. Therefore, hoteliers could make a good marketing and explore benefits of green practices (Deraman et al., 2017). GHP has positive impacts at: $a$ ) business \& hospitality, $b$ ) guests, c) local residents, and finally, $d$ ) the 
sustainable development of a destination. Hotel operators should try to build a hotel green image by implementing material and non-material green advertisement and activities, etc.

Despite the benefits hoteliers may gain, the Sarajevo lux hotels' participation in green practice is somewhat neutral (as the $52 \%$ is not a quite validated frequency of $60 \%$ that would be counted as a representative instead statistical majority) mostly due to the lack of governmental or relevant institutional support (as there's no GHP Public Statement neither the legislative strategy for sustainable development of hospitality industry), but also because there is no exist a full/or systematic environmental monitoring. The initial stage of the hotel is the best way to implement green concept, but Amandeep (2017) stated that "even an already running hotel may also turn the hotel into an environmentally friendly hotel by following and respecting the environmental legislative procedures". As Sarajevo is a tourism developing destination, it's a good timing to welcoming the world recognized hotel chains that already owns and bringing the GHP certificate in the place.

Toward the implementation of green practice at the hotels, the International Tourism Partnership (Green Hotelier) expressed 5 ways tech that can make a hotel more responsible: a) ecofriendly heating and energy that reduce energy consumption by up to $10 \%$; b) waste reduction technology, e.g. composting and pulping, c) sustainable laundry like "bead cleaning" that helps hotels to reduce their energy and water usage, d) lighting technology such as occupancy sensors or LED lighting, e) iPad POS systems (Green Hotels Association, 2009).

However, there's an expensive (e.g. the high green tech or international environmental certifications for hoteliers) and the cheap (e.g. re-use towel program or LED lighting) green practice. Deraman et al. emphasized "it is not necessarily for hoteliers to involve capital intensive projects during the introduction of environmental practices and policies; instead, it can be started with low cost, simple projects that can be implemented by employees" (Deraman et al., 2017). Small steps make a big environmental difference.

\section{Conclusion}

The results of this article will help hoteliers and hotel developers to think "green". By providing GHP, hoteliers can begin to understand that environmentally friendly attributes are important not only for "saving the Planet" but for their economical and health benefits as well.

There are many simple and cheap ways to incorporate green attributes into the guest room. Hoteliers can easily start building the green concept of hotel and they can even promote it like environmentally-friendly brand which is also modern and trendy.

On the other hand, the government need to recognize the importance of the legislative environmental framework of hospitality development and to support the green hoteliers. Therefore, the paper brings an educational guide for sustainable hospitality as it reflects its negative impacts on the environment, but the concept or the tools of environmental practices in hotels as well. The research should initialize environmental awakening and legislative implementing of GHP at the state level. Tourism and spatial planning sector (and all the relevant institutions and local authorities) should create the tourism master plan of Sarajevo and the official strategy for sustainable hospitality development.

There should also be implemented the systemic environmental monitoring at hotels and tourism destination of Sarajevo. Therefore, it would enable the relevant sources of data in each environmental section presented here.

The research was focused on the lux hotels only, but it is same time input to create new studies that will enable measuring environmental practices at wider range of hotels in Sarajevo tourism destination. That could be even more significant because the positive results toward the research objectives were expected here from the first class of hotels (lux category), while the lacks of green attributes could be found at the lower ranked hotels.

\section{References}

Amandeep, 2017 - Amandeep, A. (2017). Green Hotels and Sustainable Hotel Operations in India. International Journal of Management and Social Sciences Research, Vol. 6, No. 2, SLAA Publications, Bangalore.

Cantonal Plan... - Cantonal Plan of Environmental Protection of Sarajevo Canton for the period 2016-2021 year, 2017. Ministry of Spatial planning, building and environmental protection, Sarajevo. 
Council of Ministers, Bosnia \& Herzegovina, 2012 - Answers to the List of EU Questions on Chapter 27 - Environment, Sarajevo.

Deraman et al., 2017 - Deraman, F., Ismail, N., Arifin, A., Mostafa, M. (2017). Green practices in hotel industry: Factors influencing the implementation. Journal of Tourism, Hospitality \& Culinary Arts, Vol. 9 (2), pp. 305-316, Malaysia.

Ekopak - Ekopak [Electronic resource]. URL: https://www.ekopak.ba/bs/ news/347/prezen tovani-podaci-o-plasmanu-i-recikliranju-ambalaznog-otpada-u-segmentu-sdg-indikatora

FMOIT - FMOIT [Electronic resource]. URL: https://www.fmoit.gov.ba/bs/ turizam/kategorizacija

Gc-Mark - Gc-mark [Electronic resource]. URL: https://gc-mark.com/gc-marks/hotelsrestaurants/green-hotel-questionnaire/

Gössling et al., 2012 - Gössling, S., Peeters, P., Hall, M., Ceron, J.-P., Dubois, G., Lehmann, L.V., Scott, D. (2012). Tourism and water use: Supply, demand, and security. An international review. Tourism Management, 33, Elsevier.

Green Hotels Association, 2009 - Green Hotels Association, 2009 - Impact (2009). Journal of GHA, Houston.

Greenhotelier - Greenhotelier [Electronic resource]. URL: http://www.greenhotelier.org/ best-practice-sub/talking-point/5-ways-tech-can-make-your- hotel-more-responsible/

Johanson, 2014 - Johanson, M. (2014). Is It Safe to Travel to Sarajevo? 10 Taboo Destinations And Why You Should Visit Them. International Business Times, New York.

Kadric, 2017 - Kadric, S. (2017). Factors Of Hospitality in Sarajevo Canton. Graduate Paper.

Mentor: Zunic, L. Faculty of Science, University of Sarajevo, Bosnia and Herzegovina.

Kreag, 2001 - Kreag, G. (2001). The Impacts of Tourism, University of Minnesota, USA.

Kurtovic, 2008 - Kurtovic, H. (2008). Corridor V-C as a mechanism of tourism improvement in Bosnia \& Herzegovina, Proceedings- Traffic influence on the regional development, University of Tuzla.

Leung et al., 2014 - Leung, Y.-F., Spenceley, A., Hvenegaard, G., Buckley, R. (2014). Tourism and Visitor Management in Protected Areas. IUCN World Parks Congress, Sidney.

Millar, Baloglu, 2008 - Millar, M., Baloglu, S. (2008). Hotel Guests' Preferences for Green

Hotel Attributes. The University of San Francisco.

Müller, 2004 - Müller, H. (2004). Tourism \& Ecology, Masmedia, Zagreb.

Nurkovic et al., 2006 - Nurkovic, S., Miric, R., Dreskovic, N., Jahic, H. (2006). Regional Aspect of Tourist Potentials of Sarajevo Canton - Classification \& Valorisation. Proceedings Tourism as a factor of regional development, University of Tuzla.

Ogbeide, 2012 - Ogbeide, G.-C. (2012). Perception of Green Hotels in the 21 Century. Journal of Tourism Insights, Vol. 3, Is. 1, Grand Valley State University.

Statistical Service Centre, 2001 - Approaches to the Analysis of Survey Data (2001). Statistical Service Centre, The University Of Reading, UK.

Strategies... - Strategies of the Pan-European Transport Corridors and Transport Areas,

Development and Activities in 2000 and 2001, 2002. Transport Strategies, The European

Commission, DG Energy and Transport, Final Report, TINA, Vienna.

ZPR - ZPR [Electronic resource]. URL: https://zpr.ks.gov.ba/preuzimanja/publikacije

Zunic, 2012 - Zunic, L. (2012). Tourist Traffic and Tourism Profit of Sarajevo city as Reliable Indicators of Tourism Development. Journal Of International Environmental Application And Science, Vol. 7, Is. 2, Konya, Turkey.

Zunic, 2018 - Zunic, L. (2018). Tourism of Sarajevo - Receptive Cultural Factors at the Destination. Scientific Monograph, Faculty of Science, University of Sarajevo.

Zunic, 2017 - Zunic, L. (2017). Development of Sarajevo As a Tourism Destination. International Journal of Basic and Applied Science (IJBAS), Vol. 5, No. 4, April 2017. Insan Akademika Publications, Indonesia. 